\title{
Japanese Colonial Land Survey Project and Korean Economic Take-off
}

\author{
Zonghie $\operatorname{Han}^{1}$ \\ ${ }^{1}$ Department of Real Estate, Daegu University, South Korea \\ Correspondence: Zonghie Han, Department of Real Estate, Daegu University, South Korea. Tel: 82-53-850-6383.
}

Received: September 24, 2020

Accepted: November 17, 2020

Online Published: December 10, 2020

doi:10.5430/rwe.v11n6p185

URL: https://doi.org/10.5430/rwe.v11n6p185

The research is financed by 2019 Research Program of the Daegu University.

\begin{abstract}
The mystery of the newly industrialized countries (NICs)s success, including Korea's take-off, can be addressed by using the concept of a property representation system, as initiated by de Soto (2000). This property representation system, which has been further described as the mystery of capital formation, was supposedly established in Korea during the Japanese colonialization of 1910-1945. The Korean industrialization in this period has been well described by the 'developmental state' approach, but the property representation system can reveal the key role of property rights as an institution in the economic take-off, focusing on its incentive function.
\end{abstract}

Keywords: property rights, NICs, land survey, take-off, Korea, Japan

\section{Introduction}

In explaining the phenomenon of the Newly Industrialized Countries (NICs), the established approaches can be divided into several schemes, from 'Confucian culture' via 'multinational corporation strategy' and 'developmental state to 'human capital'. Most of these approaches focused on the socioeconomic circumstances after their political independence, assuming that the NICs had to start from zero and that a large interruption existed between colonized and independent societies (Hori, 1995, p.viii). Eckert (1991) and Kohli (1994) therefore established the concept of 'developmental state' in analyzing the economic development of Korea (Note 1) to explain one of the most rapid instances of industrialization in the modern history. The concept of 'developmental state' has been shared by the so called 'colony-modernization' approach in the debate over Korean economic history which ranges from Japanese, represented by Hori (1995), to some Korean studies, represented by Gim (2006), as opposed to the 'exploitation' approach of many traditional studies by Korean scholars.

It seems however that the 'colony-modernization' approach misses some points in attempting to explain Korea's economic take-off in the 20th century, especially with regard to its 'uniqueness'. Namely, plenty of empirical data has been presented to show that considerable economic development and industrialization took place in colonial Korea (1905-1945), which formed a foundation for the Korean economic take-off after its independence, whereas the question of "How has it been possible for only the NICs, including Korea, and not for other countries with similar historical backgrounds?" has not been sufficiently well answered. This study adopts an alternative approach introduced by de Soto (2000) that divides the modern economy into two parts, one with 'capital' and one without 'capital', in order to describe Korea's economic take-off in the 20th century and to illustrate both the success and failure of developing countries.

\section{Take-Off and the "Mystery of Capital"}

\subsection{Economic Take-Off and Korea}

De Soto (2000, p.209) argues that only twenty-five of the world's circa two hundred countries can be classified as those developed economies where the 'capital formation' has been completed, according to 'The International Property Right Index' at (http://internationalpropertyrightsindex.org/). And it seems that these 25 nations, which de Soto (2000) calls 'Western', do not differ greatly from several commonly quoted lists of 'developed countries'. One of the most cited criteria to the developed countries is the Human Development Index (HDI) of the United Nations, which can be used to evaluate the question of take-off. 
Korea belongs to the 'Top 15 Most Developed Countries in the World 2014' with an HDI of 0.891 and to the ten largest advanced economies already in 2012 by nominal GDP as well as by PPP GDP (Note 2). So Korea can be considered an economy where the take-off, according to the terms of de Soto (2000), has been established, even though Korea has a ranking of 33rd among 129 countries in the International Property Right Index List 2019 with a score of 6.6 (Note 3). Given that Korea was one of the poorest countries in the world after World War II, with a per capita annual income of 67 US dollars (1953), this economic success has been a very interesting story in economic history. Recently this success has been demonstrated in terms of the "middle income trap" by Gill and Kharas (2015).

\subsection{Mystery of Capital}

De Soto (2000)'s theoretical frame was designed to explain the chronic underdevelopment of the Third World, including Latin America, Africa, South Asia and Russia, by his own survey method and theoretical scheme. His basic concept is that the essential element of the modern market economy or modern capitalism consists of 'transformation of assets to capital', leading to the 'property representation system', so the concept of 'capital' is distinctively defined rather than the conventional meaning of capital in the academic and journalistic field. In his local research on Latin America, South-and Middle Asia, Africa and East Europe, de Soto (2000) concludes that even the fast-developing countries such as South Africa, Mexico, Brazil, Indonesia and Philippines, which were showing remarkable economic growth in the early 2000's, do not belong to economies where the 'capitalization process' has finished. He offers plenty of empirical data showing that those economies possess sufficient assets, consisting mostly of real estate, but that those assets failed to be converted to the "fungible capital" that is necessary for the take-off. Physical assets of housing, building and land should be integrated into a single formal representational system that includes not only the official register system but also the modern social contract on property, so that they can be traded outside of narrow local circles where people know and trust each other, as well as used as collateral for a loan or as a share against an investment. Assets are thereby turned into 'capital', which is in that sense not money or means of production, but a social institution. This notion of capital corresponds to the estimation of the total capital or total wealth by the World Bank(2006), 'the Millennium Capital Assessment' for the year 2000, in which 'intangible capital' constitutes the largest share, $78 \%$, of total wealth worldwide. Meanwhile, the shares of natural capital and produced capital are only $4 \%$ and $18 \%$, respectively (Note 4). Intangible capital is measured as the difference between total wealth and the other produced and natural stocks. Notably, such 'residual', which is comparable to the so called 'Solow residual' of Solow (1957), is much larger than tangible and measurable capital in forming economic and social wealth. Intangible capital "includes human capital, the skills and know-how embodied in the labor force...[and] encompasses social capital, that is, the trust among people in a society and their ability to work together for a common purposes. It also includes all those governance elements that boost the productivity of the economy...[such as] an efficient judicial system, clear property rights, and an effective government" (Note 5). Intangible capital therefore underpins de Soto (2000)'s definition of 'capital' and capitalization by revealing that it is the preponderant share of wealth in virtually all countries, with the share increasing with increasing income. It appears that de Soto (2000)'s concept of capitalization specifies some aspects of intangible capital by the World Bank by focusing on the function and effect of the 'property representation system', which is regarded as a mere component of an 'efficient judicial system' in intangible capital. De Soto (2000)'s idea of capital formation by the integrated property system extracts only a tiny part of intangible capital and replaces it as the most essential factor in explaining take-off. On one hand, it can therefore be criticized as being very narrow and confined, whereas on the other hand, it could be a very powerful framework for explaining the mystery of modern economic growth due to its concentration on the property rights. This concept of intangible capital is supported partially by the empirical model of the World Bank (2006, p.13), in which the 'rule of law index' emerged as the largest coefficient (0.83) in explaining intangible capital, far exceeding the next variable 'school year index' of 0.53 .

The concepts of the intangible capital and the property representation system can be applied to the economic take-off of Korea, whilst the process of Korean capitalization can be addressed by considering some socioeconomic aspects of the Land Survey Project (1910-1918) under the Japanese colonial occupation (1910-1945).

\section{Land Survey Project (1910-1918) and Property Representation System}

\subsection{Property System as a Socioeconomic Process}

The Land Survey Project in Korea which was performed from 1910 to 1918 by the Japanese Colonial Government General, was not only a cadastral survey in the technological sense, but can also be credited with creating the modern legal property system, including a property register in line with the German civil law framework. It is worth noting that merely instituting an appropriate legal system concerning property rights by means of the legislation and administrative organs does not automatically induce the property representation system. In the findings of de Soto 
(2000, p.3), "reforms directed at creating capitalist systems have been tried [in Latin America] at least four times since independence from Spain in the 1820s", but all four attempts have ended in failure (Note 6). This has to do with the definition of property rights by Rapaczynski (1996, p.88): “...most property rights can only be marginally enforced by the legal system. The core of the institution of ownership is a matter of unquestioned and largely unconscious social and economical practices that must be rooted in non-legal developments." A property representation system can be created simply neither by legislation and proclamation of Parliament, nor by a cadastral survey using modern GPS techniques (Note 7). It is a matter of institution constructed and established in the complicated socioeconomic interrelationship with the history, at least if it shall be created autonomously. This point is ascertained in Bernstein (2004, p.383)'s analysis on economic take-off, where the property rights emerges as the most critical factor of four factors enabling the economic take-off: property rights, scientific rationalism, capital markets, and modern power generation; but "not only did the other three factors become available in the modern era, they became available for the taking (italics original)." So "today, across the globe, [property rights] is what most reliably separates the haves from the have-nots." (Note 8)

However, de Soto (2000, p.173) argues that the property representation system can be created by the targeted and careful institutional approach, as the government roots the formal property law in social contracts to which people were already committed, that is "building a legal and political bridge from social contracts scattered 'on the ground' into one national law". Such 'prearranged transformation' with political motive was carried out fruitfully in Switzerland, Germany and Virginia around the 19th century, even though not so smoothly and compactly, and it seems that Korea has gone through the same process of property transformation. If the scheme of de Soto (2000) and Bernstein (2000) is accepted, i.e., if the mechanism of take-off can be abstracted to the sole problem of property rights, the question of Korean take-off is narrowed to the issue of acquisition of the property representation system in Korea. So it would be reasonable to question which actions of the Japanese colonial governance, in which the foundation for Korea's rapid industrialization were formed, had the greatest contribution to the formation of the property representation system.

According to the 'colony modernization' approach explaining Korea's economic success, the introduction of modern law institutions was one of the key factors which had led to the rapid formation of Korea's market economy system. Lee (2005, p.194) listed some observations demonstrating the imperfection and backwardness of the Korean traditional property system before the colonialization, and counted the legislation of the civil law, commercial law, real estate registration act and patent law in 1910-1912 as one of the main factors which induced the Korean economy down the road to rapid industrialization. More precisely, Lee (2005, p.200) admits that the modern property system "was established" by the legislation and enforcement of the colonial government. This is precisely what de Soto (2000) denies, backed by plenty of cases in the Third World in which the modern lawmaking was proclaimed but miscarried, again and again failing to settle down the modern property system. The fact that the new colonial power provides new legal codes does not automatically lead to a new social order. Compared to the despairing institutional situation of the traditional Korean society, it is quite impressive that the Japanese governance created 'law and order' in the Korean society, but de Soto's approach reveals that it is by no means self-evident, and rather belongs to the realm of mystery in general. It seems at a glance quite evident, not mysterious, because everything happened very quickly in Korea; however, an examination of many other comparable countries reveals the exceptionality of Korea's success story: Land survey projects and (accompanied like in Korea) legislation procedures introducing modern property rights itself can be found everywhere in the history of economic development, from Africa to early modern Europe, resulting evidently in antithetic outcomes. Consequently, this study concentrates on the Land Survey Project (1910-1918), which was implemented over 9 years by the hands of a 'developmental state' with the highest degree of execution and efficacy, by asking whether it took as the basis of the property representation system in the sense of de Soto (2000), because it dealt with the social and economic field work affecting every transactor on the market, other than mere political gesture or isolated paper work on the table.

\subsection{Land Surveys Before the Japanese Colonialization}

Years before the Land Survey Project under Japanese occupation (hereafter referred to as the 'Colonial Survey') the Korean royal government carried out its last land survey, the 'Gwang-Mu Survey' from 1898 to 1904. The traditional land survey of Korea's royal government, called 'Yang-Jun', which aimed to determine the liability of land tax, should occur every 20 years according to the 15th century Constitution. However, after the first survey of 1391, the next surveys were documented only in the 1480s, 1593-1594, 1603, 1613, 1634, 1663-69, 1701, 1709 and 1719-1720, and even these were mostly only local surveys and not nationwide. The Gwang-Mu Survey, conducted 180 years after the previous survey of 1720, called 'Gyung-Ja Survey', was supposed to correct the long-term disorder and chaos in the land tax management and to introduce Western culture. At its end in 1904, the Gwang-Mu Survey remained incomplete, leaving many legal and practical questions unanswered. 
The Gwang-Mu Survey, along with its precedents, suffered the following limitations from the modern viewpoint:

- Separation of real owner and 'nominal' owner on the Register Book (Note 9). The 'nominal' owners on the Books were in most cases the servants or butler of the 'real' owners of land who positioned themselves as the noblesse of Lee Dynasty (1392-1910) of Korea. Because the Korean aristocratic class ('Yang-Ban') had a land tax exemption, like in medieval France, and the farmers were liable to land taxes, irrelevant peasant or owner, most aristocrats regarded it as a disgrace to be named on the Book, even though after the 18th century the tendency of unifying nominal and real owner increased (Note 10). Yet this duality caused no difficulties in the taxation practice because the identity of the righteous owner of the land was clear for both parties: taxpayer and tax officer. Nevertheless, this meant that the property rights functioned as a narrow social contract in the sense of de Soto (2000), and restricted the validity of the boundary of property rights to the familiar relationship of the neighborhood. Creating capital or transforming assets to capital requires expanding the whole potential of land assets to the long distance of un-anonymity and openness as far as possible.

- The feudal concept of 'Royal Domain'. The principle which says that the monarch is authorized to possess the whole land property while all other people are supposed to lease land for the usage without the possibility of buy and sell, had been maintained valid, at least officially, until the last day of the dynasty.

- Lack of steady management of Books. Although the importance of Books at land transactions had increased after the 17th century, the sustainability of this property system was not guaranteed in the 18th and 19th centuries. It means that the Book did not track the change of owners, and no longer matched the private land sale contracts after surveys. In many cases the entries of the Books remained unchanged for more than 200 years. However the growing discrepancies became a burden for society, which motivated the Gwang-Mu Survey in 1898.

- Lack of consistency between family register and land register. Although the usage of full name, including surname, had been settled in making the Books, those names did not correspond the names on the family register (Note 11). The family register worked for the management of military service and tributary payment, and over the entire half millennium of the dynasty, no attempt had ever been made to establish a one-to-one relationship between the names in the family and land registers. This considerably hindered the establishment of the modern property system, which demands overcoming any anonymity, exhibiting the specifiability and legal liability of any individual. The Colonial Survey realized the correspondence between the two registries for the first time in Korea.

- Lack of assertiveness of the land survey management of central and local governments. Aside from the aim and appropriateness of the land survey, the political system of Korea's royal government did not have any clear strategy or executory power in general. The absence of ministers or high-ranking officials equipped with planning and management competency, as well as the absence of the subordinate officials who were responsible for the enforcement of government policies equipped with practical competence, was distinctive throughout the entire Lee Dynasty (Note 12). In contrast, the Japanese Colonial Government General had a well trained bureaucracy, even though fortified by some police force support, which was able to implement effectively the precisely planned government policy (Note 13). This has to do with the definition of the 'Developmental State' defined by Kohli (1994, p.1270), where Japanese influence transformed Korean society "from a relatively corrupt and ineffective social institution into a highly authoritarian, penetrating organization".

The problem of discrepancy between nominal and real owners seemed to have improved in the 17th century, accompanied by the socioeconomic progress at that time, but the positive trend did not hold out in the 18th and 19th centuries. In some cases the progress was retarded, with some of the benefits gained in the 17th century being lost, especially regarding the concept of land ownership liberated from the principle of the Royal Domain and the existence of various 'assumed names' appearing on the Books. The tendency of official approval of the private property rights in the 1720-Survey was reversed at the Gwang-Mu Survey, in which the terminology 'owner of time' in direct translation and 'temporary owner' in liberal translation were used in order to underline and clarify the principle of Royal Domain (Note 14). It was a temporary ownership, because at any time the state or monarchy, the 'genuine' owner, was authorized to withdraw or change the temporary ownership over land. This also implies the prohibition of civil land market as a rule. Lee (1997, p.171) shows that the principle of Royal Domain had been so appealing to the bureaucratic elite system and the wide gentry-scholar group bearing it, that even the most famous and widely admired scholar Jung Yak-Yong (1762-1836) claimed that the Book should stop using the terminology 'owner' and replace it to 'temporary occupant'.

These points suggest that the traditional surveys, including Gwang-Mu, cannot be identified as having established the modern property rights, contrary to some studies arguing over the modernity of the Gwang-Mu Survey (Note 15). 
From the viewpoint of de Soto's approach, it seems quite clear that the land surveys carried out in the Korean traditional society did not satisfy the requirements for a property representation system, resembling more or less the characteristics found in the Third World and described by de Soto (2000).

\subsection{Colonial Survey as a Modern Institution}

In preparing for the Colonial Survey, Japanese began with a fact-finding mission. In 1906 (Note 16) the Japanese Resident-General of Korea set up the 'Research Commission for Real Estate Law,' which aimed to investigate whether the same property rights as the Japanese Civil Law of 1898 existed in Korea. In 1909 the 'Essentials to Land Survey' was published by the Treasury Department. The Japanese conclusion was as follows:

- There existed no legal land property rights in Korea (Yi, 2008, p.123).

- Entire land institutions, including the taxation system, were in disorder (Yoon, 2003, p.5)

- New Land Survey was inevitable for the formation of the land institution and the taxation system. One of the finest examples was the German (Prussian) land survey conducted in 1861.

After the official annexation of the Korean peninsula in 1910, Japanese Government General in Korea proceeded with the Colonial Survey. The Survey Project consisted largely of investigation and measurement. It included the following:

- ascertainment and identification of the name and border of towns; the location, area, border, yield, rent, class and category of a piece of land; the name and address of owner

- triangulation, cadastral mapping and drawing of rough town-maps

- creating a new address system by giving new numbers to land pieces.

Its outcomes were a land register, cadastral map, land investigation record and land tax register. These outcomes were displayed to the public for 30 days during which period anyone could make a formal objection. In the absence of any objection, and if any objection was accepted or denied through the decision of the High Land Survey Committee, the land ownership was granted legally as a form of original acquisition.

The Government General mobilized about 5,000 officials and spent 3.2 billion US dollars in today's money for the Colonial Survey (Note 17).

As aforementioned, the property representation system does not arise from legislation activity alone. As for the administrational competence, the Japanese implementation was very careful and elaborate. Under the perspective of 'eternal annexation' of the Korean peninsula (Kim, 1997, p.31) (Note 18), it seems that Japan tried its best to consolidate the political and social foundation in Korea at the Colonial Survey, supported by the following points:

- The cadastral surveys deployed equipment and techniques that were more advanced that those used generally in Japan (Chun, 2008, p.24)

- The most stressed principle during the investigation and in any dispute conciliation was fairness. The action officials for the Survey were often warned and submitted to disciplinary measures owing to nuisance and high-handed processing (Kim, 1997, p.32). Additionally, the Japanese profiteers and brokers were prohibited from the Survey areas.

- The survey and legal creation of land property rights were processed as a rule by the 'application principle', following the German and Japanese civil law. But the applications of would-be owner were closely investigated and compared by means of other materials, such as Land-Tax-Lists (Choi, 2003, p.290).

- The management of the Colonial Survey was cautious and flexible, in order to minimize the resistance of the residents and to give an impression that the Survey is not for the Japanese but for the Koreans themselves. A good example is the cases of an application deadline being postponed many times. Eventually, the Koreans were ready to cooperate on the Survey after their initial distrust (Kohli, 1994, p.1277).

As a result, almost all sections of land (arable and dwelling areas) (Note 19) were identified with proper owners, without any notable protest or resistance. Overall, 19,107,520 pieces of land totaling 48,223.61 $\mathrm{km}^{2}$ were surveyed, and $99.5 \%$ were by application (Choi, 2003, p.284). Moreover, the Colonial Survey was accompanied by a census and the creation of a new family register, which enabled a one-to-one match of the land and family registers, connected with a constantly updated system based on recognized addresses. Government and public institutions were registered as the legal owner of their land, losing all privilege and being treated as equals with civil persons in the civil law system. Various usufructuary rights overlapping on a piece of land, which constituted a part of the chaos, were either abolished or substituted to modern usufruct (Choi, 2003, p.268) (Note 20). 
Along these lines, it seems that the Colonial Survey of 1910 to 1918 completely overcame the aforementioned chronic problems of the Korean traditional society that had blocked the creation of a property representation system, most clearly shown in the Gwang-Mu Survey. The legal and social structure established by the Colonial Survey has been maintained effective until today in Korea, although only in the southern half of the peninsula, without any fundamental distortion. But from the viewpoint of the long and mysterious process of generating the property representation system described in de Soto (2000) as well as in North and Thomas (1973), it should be asked whether the rapid transformation of the institution at a single stroke accompanied a significant economic outcome. So the economic effects of the Colonial Survey need to be examined.

\subsection{Economic Development in Colonial Korea and Thereafter}

There is no quantitative consensus regarding Korea's economic activity in the colonial period. Aggregations of GDP show disagreement in the studies of Suh (1978), Mizoguchi (1988), Hori (1995) and Gim (2006), but the qualitative picture seems quite unanimous: Korea experienced rapid economic growth in the colonial period. It can be summarized in three graphs: Figure 1, Figure 2 and Figure 3.

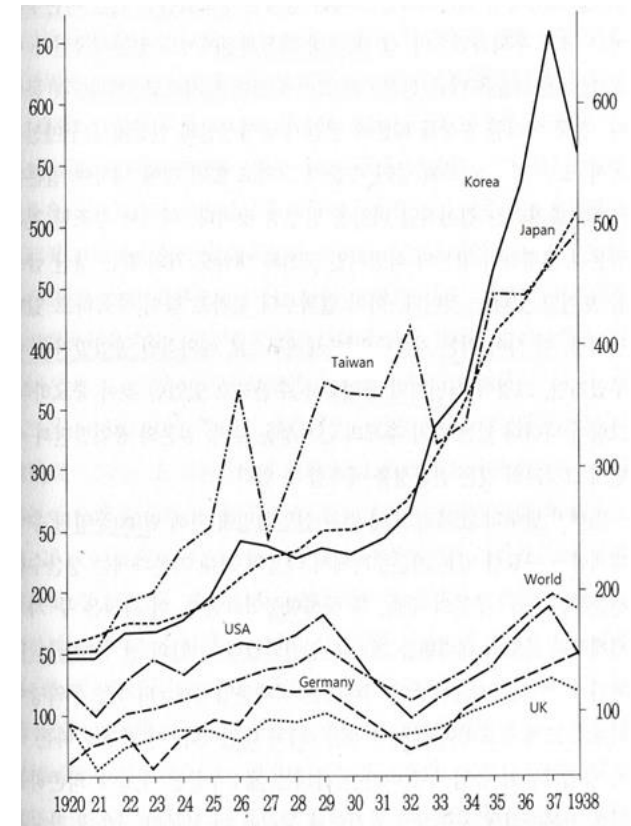

Figure 1. Industrial production index $(1913=100)$

Source: Mizoguchi(1988); recited from Hori (1995) p.37

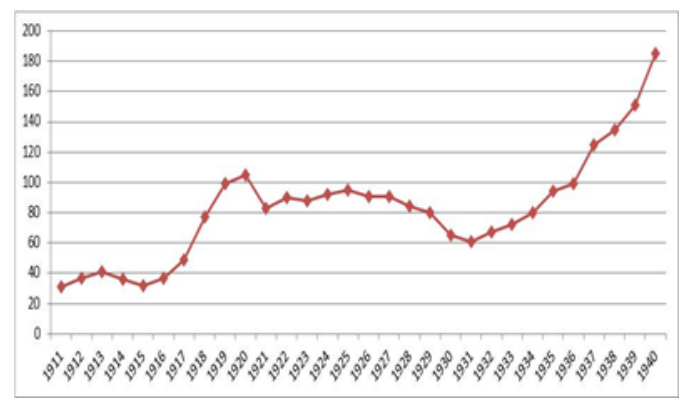

Figure 2. GDP of colonial Korea (mil. Yen)

Source: plotted from data in Gim (2006) p.351 


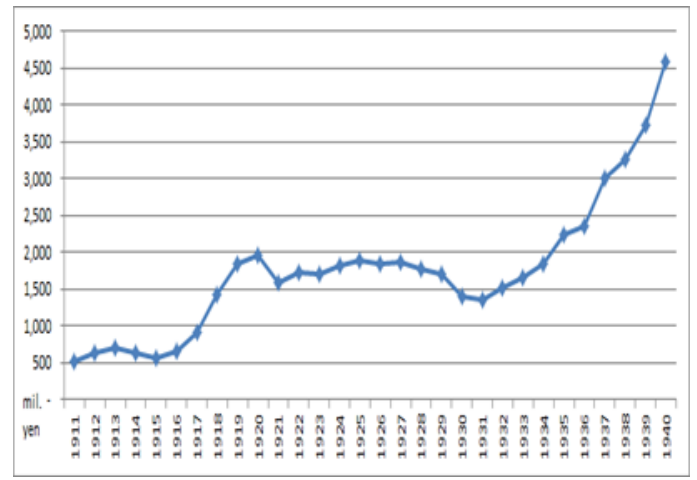

Figure 3. GNI per capita of colonial Korea (Yen)

Source: plotted from data in Gim (2006) p.353

Korea shows the most remarkable increase in the industrial production index, from 100 in 1913 to nearly 650 in 1937, ahead of Taiwan and Japan. GDP increased by an average annual growth rate of 3.6\% during 1912-1939. Income per capita rose six-fold from 30 to 180 Yen. The growth of trade was more dramatic, 51-fold in exports and 35-fold in imports (Hori, 1995, p.34). Nearly 35\% of GNP in 1940 originated in mining and manufacturing, which indicates 'a relatively advanced level of industrialization'(Kohli, 1994, p.1270) (Note 21). The rapid growth began to falter after the outbreak of the Sino-Japanese War in 1937 due to the economic blockade of the Western countries, and the whole Japanese economic bloc maintained a wartime economy until 1945. As the Japanese army expanded in the invaded areas in China and South Asia, Korea acted as a rear supply base. The following facts are found in colonial Korea:

- The population had increased by more than $80 \%$ from 13 million in 1910 to 26 million in 1945 , allowing for statistical errors (Huh, 2007, p.6). This mainly arose from the drastic fall of mortality, especially the infant mortality rate, thanks to the introduction of the Western public health and vaccinations.

- Macroeconomic consumption (per capita) increased with an average annual growth rate of 3.3\% (2.3\%), resulting in 2.38-fold growth 1912-1939(Gim, 2006, pp.205) (Note 22).

- Rice consumption per capita decreased, not due to the Japanese 'exploitation', but because the expanded rice production was exported to Japan as a profitable business. Engel's coefficient dropped. The percentage of elementary school attendance rose from $2 \%$ to $40 \%$ (Zhoo, 2005, pp.321-343).

- While the urban residents enjoyed the fruits of economic growth, the situation of peasants in the countryside was often worsened, partly because their traditional usufruct on land had been denied at the Colonial Survey, but also owing to the worldwide agricultural crisis in the 1930s, as well as to the sudden population growth. Hence some 2 million emigrated to Japan and northern China (Lee, 2008, p.95).

Korea's industrialization was an outcome of various interacting aspects. First of all, the colonized society was ready to focus on economic development. Kohli (1994, p.1279) showed that the productive transformation in Korean agriculture was a necessary component of rapid economic growth in 1930s: The settlement of modern property rights on real estate and the introduction of new technologies relating to irrigation, drainage, and reclamation, as well as improved seeds and fertilizer, led to a 'green revolution in agriculture', which subsequently contributed to the formation of entrepreneurial strata from big land owners via massive export of rice, as well as to the emergence of a domestic market for manufactured goods. The new form of export-oriented alliance between the power groups for the common interests was backed by several actions of the Government General, such as the installation of infrastructure - above all roads, railways, electricity and communication -, reformation of currency and banking, embedding of the modern and independent judiciary (Note 23), and minimization of wages. These policies were supported by an organized training system in which Korean policemen, officials, technicians and workers were transformed into loyal co-actors in the industrialization process. The relatively autonomic Government General was also a positive background, as it could conduct an independent industrial policy for the Korean peninsula, other than that for Japan, namely the aggressive 'economic development plan', even though it was no other than a copy of the development strategy undertaken by Japan itself decades previously (Note 24). Manufacturing was rather depressed in the early stage of the colonization in order to protect Japanese exports to Korea, but after World War I Japan needed to export the excess capital in the course of rapid growth, relaxing more and more restrictions against manufacturing. In 
the face of the Great Depression, the invasion of Northern China (Manchuria) and the diplomatic tension with the West, Japan wanted to create a protected economy block within the empire, above all as a market for Japanese products. Trading within this block was relatively free of tariffs and other restrictions, and some regulations against economic activities were even withdrawn for the Korean peninsula (Gim, 2005, p.294). So regular industrialization in Korea had begun. "Relatively small-scale, Korean household industries continued to mushroom... the role of Japanese factories as 'Schumpeterian innovators' were followed by 'clusters' of Korean imitators... and forward and backward linkage [was] created by Japanese investments”(Kohli, 1994, p.1280).

Korea's rapid industrialization in the 1930 s took the path of hefty export-orientation, which can be sharply contrasted to many other developing economies of the Third World with their 'import substitution' pathway: the ratio of foreign trade to GDP in 1938 was $65.1 \%$ and $31.2 \%$, respectively, for Korea and Japan (Hori, 1995, p.34). This shows that Korea's dependence on foreign trade was far more critical than was Japan's, even though its export-leading development strategy was imitated by Korea. As a result, Korea was exporting more than twice as much as any comparable economy in the 1930s, with $43 \%$ of exports being manufactured goods. This structure of economic development has endured until today, without being altered fundamentally by the American Trusteeship 1945-1948 in the South (Kohli, 1994, p.1285) (Note 25).

Korea's industrial and financial facilities were almost completely destroyed during the Korean War (1950-1953), so some argue that Korea had to start from scratch after independence from Japan and the war (Note 26). But approaches based on the concepts of de Soto (2000)'s property representation system and the World Bank (2006)'s intangible capital would suggest a considerably restricted role of physical damage in the economic development. Bernstein (2004, p.23) gives appropriate examples of Germany and Japan after World War II.

\section{Conclusion}

The Korean Land Survey under Japanese colonial rule may have been a crucial procedure to create a property representation system which finally formed the foundation for the Korean economic take-off, by creating a mechanism "to bring social and private rates of return into closer parity (North and Thomas, 1973, p.2)", notwithstanding the fact that a government announcement and enactment does not routinely lead to the construction of a property representation system. In fact the Japanese governance seems to have been aware of this point already at the beginning of the Survey: "Land can be transformed to other assets or can be collateralized in financial institutions for the swift cash flow, only when its rights are safe...otherwise the fixed capital would not be transferred to circulating capital...resulting in the despairing situation in which no industry other than agriculture could survive in this country...credit is one form of immaterial capital...utilities of capital and credit cannot be developed in societies where the institutions on the sole asset of the economy, land, are not perfect."(Yoon, 2003, pp.7-8)

The importance of the property rights in the Korean take-off has been not neglected in previous studies, for instance by Lee $(2005,194)$ with the 'colony modernization' approach. However, focusing on the property representation system as an implicit, long-run and maybe mysterious process buried in the intricacies of its formal property system in order to explain the economic take-off of developing countries would expand the understanding of economic history and facilitate more extensive comparative analyses backed by the quantitative data. The most interesting and important case study will of course be that of China: What is the actual property rights situation in China, where the ownership of land is monopolized by the state and only the rights to use land are tradable in the market? Can the paradigm of 'developmental state' be applied to China? Will it remain the only and huge exception to the property representation system or will China's embryonic take-off falter owing to the defective property representation system?

Many other questions remain to be answered: It should be clearly demonstrated how the 'developmental state' created the property representation system in a short period along with the interaction with other policies and market situations. The cases of 'failed developmental state', in which the political leadership and police enforcement were very strong, but failed to take off due most commonly to endemic corruption and a weak property system, should be examined in detail. Only the specificity and uniqueness of the Japanese expansive imperialism can be postulated to have induced its old colonies to take-off together.

\section{References}

Bernstein, W. J. (2004). The birth of plenty: how the prosperity of the modern world was created. New York: McGraw-Hill.

Choi, W.-G. (2003). Investigation and adjudication of property right in the land survey project. Studies on Korean Modern History, 25(6), 260-309. 
Chun, Y.-G. (2008). The comparative study on the recognition of aims in land survey (1910-1918). Journal of Korean Cadastral Information, 10(2), 21-33.

De Soto, H. (2000). The mystery of capital: why capitalism triumphs in the west and fails everywhere else. New York: Basic Books.

Eckert, C. (1991). Offspring of empire:the koch'angkims and the colonial origins of korean capitalism, 1876-1945. Seattle: University of Washington Press.

Gill, I., \& Kharas, H. (2015). The middle-income trap turns ten. Policy Research Working Paper 7403, World Bank. https://doi.org/10.1596/1813-9450-7403

Gim, N.-N. (2005). Evolving of the Colonial Industrialization. In D.-K. Lee (Ed.), New perspective on history of korean economic development (pp. 283-315). Seoul: Nanam.

Gim, N.-N. (2006). Economic growth in Korea 1910-1945. Seoul: Seoul National University Press.

Hori, K. (1995). Historical analysis of korean industrialization. Economics Series of Kyoto University.

Huh, S.-Y. (2007). Issues of colony modernization approach. Oriental Studies, Dankook University, 41(2), 227-250.

Kim, B.-J., \& Lee, H.-G. (2013). The study of land investigation business by Japanese imperialism during the colonial era. Management History Studies, 28(1), 55-74. https://doi.org/10.22629/kabh.2013.28.1.003

Kohli, A. (1994). Where do high growth political economies come from? The Japanese lineage of Korea's "developmental state". World Development, 22(9), 1269-1293. https://doi.org/10.1016/0305-750X(94)90004-3

Lee, Y.-H. (1997). The transition of definition and description of 'owner' on the 'Yang-An' survey. In H.-S. Kim (Ed.), Studies on the Korean land survey project (pp. 53-198). Seoul: Minumsa.

Lee, Y.-H. (2005). The Establishment and Development of Market Economy System. In D.-K. Lee (Ed.), New perspective on history of korean economic development (pp. 193-218). Seoul: Nanam.

Lee, Y.-H. et al.. (2008). An alternative textbook; modern history of Korea. Seoul: Giparang.

Miyajima, H. (1997). A Comparison of the Gwang-Mu Survey with the Land Register of Japanese Survey. In H.-S. Kim (Ed.), Studies on the korean land survey project (pp. 199-248). Seoul: Minumsa.

Mizoguchi, T. (1988). Economic statistics of former Japanese colonies: estimation and analysis. Tokyo: Toyo Economic Newspaper.

North, D., \& Thomas, R. P. (1973). The rise of the western world, a new economic history. Cambridge: Cambridge University Press. https://doi.org/10.1017/CBO9780511819438

Park, S.-H. (2001). The establishment of land property right and land survey. Studies of Gyungbuk Foreign Language Techno College, 7, 289-305.

Rapaczynski, A. (1996). The roles of the state and the market in establishing property rights. Journal of Economic Perspectives, 10(2), 87-103. https://doi.org/10.1257/jep.10.2.87

Solow, R. (1957). Technical change and the aggregate production function. Review of Economics and Statistics, 39(3), 312-320. https://doi.org/10.2307/1926047

Suh, S. C. (1978). Growth and structural changes in the korean economy, 1910-1940. Harvard East Asian Monographs 83. Harvard University Asia Center. https://doi.org/10.2307/j.ctt1tg5jct

Wang, H.-J. (1991). Various characters and narrow viewpoints. History and Reality, 6(12), 315-326.

World Bank. (2006). Where is the wealth of nations? measuring capital for the 21st century. Washington, D.C.

Yi, Y.-H. (1991). Trends and tasks concerning studies on the Gwang-Mu survey. History and Reality, 6(12), 327-343.

Yi, Y.-H. (2008). Japanese land survey project and it's record keeping. Studies in History and Culture, 30, 119-152.

Yoon, D.-S. (2003). Land survey project and disposal of land property in korean empire government. Theory and Practice of Civil Law, 7(1), 1-26.

Zhoo, I.-J. (2005). Standard of Living of the Colonial Koreans. In D.-K. Lee (Ed.), New perspective on history of korean economic development (pp. 317-348). Seoul: Nanam. 


\section{Notes}

Note 1. In the following discussion, Korea refers to "South Korea" in the post-colonial period, meanwhile for the period 1910-1945 Korea refers to the Colonial Korea as a part of Japan, including the North Korea of today. Korea before 1910 refers to the Korean Kingdom, Chosun Dynasty (1392-1910).

Note 2. http://www.imf.org/external/pubs/ft/weo/2012/01/weodata/index.aspx.

Note 3. https://www.internationalpropertyrightsindex.org/country/korea-rep.

Note 4. The intangible capital in low-income, middle income and high-income OECD countries comprises 59\%, $68 \%$ and $80 \%$ of total wealth, respectively.

Note 5. World Bank (2006) p.87. The "institutional quality" or "governance" can be divided into six dimensions: Voice and accountability, Political stability and absence of violence, Government effectiveness, Regulatory quality, Rule of law and Control of corruption (World Bank, 2006, p.92).

Note 6. "In Peru, for instance, the government had tried to formalize property at least 22 times in the four hundred years since the Spanish conquest. Their success rate: zero."(de Soto, 2000, p.170)

Note 7. "In 1993, a World Bank expert warned that 'there has been a tendency to consider land titling a technical problem. Often the maps are made and surveys carried out, but the titles are not made or issued because of a blockage in systems or legal problems."'(de Soto, 2000, p.203)

Note 8. "Physics, engineering, economics, and law can be taught at any university or gotten from any bookstore. Capital can be obtained from across town and, if not at hand there, from a foreign bank. Roads can be built, and automobiles, aircraft, computers, and cell phones can be easily purchased.” (Bernstein, 2004, p.383)

Note 9. Called as 'Yang-An'. In following abridged as 'Book'.

Note 10. At the Survey of 1719-1720, the ratio of real owner represented in the Books is more than $70 \%$ in some regions of Korea. At the same time both surnames and given names began to be documented, whereas previously only given names had been specified (Lee, 1997, p.126). Such changes were positive improvements for the transactions and lawsuits.

Note 11. Lee (1997, p.184) reported that 97\% of the names in the Gwang-Mu Survey in 1904 and Colonial Survey in 1918 did not match. In Miyajima (1997, p.231)'s study, the match ratio was 4.5\% and 14.9\%, respectively.

Note 12. Lee (1997, p.164) found many cases in which different survey guidelines were adopted in neighboring regions, and argued that there had been no institution for conflict control at the land surveys.

Note 13. Kim (1997, p.32) pointed out the fairness and strictness seen at the Colonial Survey.

Note 14. In the 1720-survey the terminology referring to land owner was 'cultivating owner'. See Lee(1997) pp.105-167.

Note 15. See Wang (1991) and Yi (1991).

Note 16. The practical Japanese colonialization in Korea started with the Japan-Korea Treaty of 1905.

Note 17. The aggregated costs of Colonial Survey were 400,000 Yen at that time (Park, 2001, p.289) and corresponded to 3-years revenue of land tax(Kim, 1997, p.31) as well as to $120 \%$ of the total revenue intake of the Government General in 1911(Kohli, 1994, p.1277). Its present value was calculated from the fact that 144kg of rice cost 3 Yen in 1910.

Note 18. Kohli (1994, p.1272) argues also: "The near geographical contiguity and shared cultural and racial traits...implied that the Japanese could realistically consider their rule to be permanent, leading eventually to a full integration of colonies into the expanded Japan." Eckert (1991, p.256) points to the "shared culture" as "Confucian values."

Note 19. Except for forest areas, which were surveyed from 1917 to 1935 after the Colonial Survey. In Korean traditional society, the forests were considered 'commons', on which numerous fierce lawsuits were aroused on account of ancestor graves.

Note 20. Many tenants, losing traditional usufructuary rights on land, caused disputes and strikes during the Colonial Survey. These conflicts died away as the Government General sold the public land to the tenants (Kim and Lee, 2013, p.66). 
Note 21. It is however $19.4 \%$ in Gim (2006)'s calculation. The proportion of mining and manufacturing in postwar Korean GDP was $8.9 \%$ in 1953 and $30.5 \%$ in 2014(See Economic Statistics System of Bank of Korea; http://ecos.bok.or.kr ).

Note 22. The average annual growth rate of world income per capita 1913-1950 was 0.9\%. For USA it was $1.7 \%$, and for Asia except Japan -0.02\% (Zhoo, 2005, p.320).

Note 23. The Korean traditional court at the time of annexation was characterized as "hopelessly corrupt"(Kohli, p.1272).

Note 24. Eckert (1991, p.255) even defined it as "overwhelming predominance of the state in economic affairs." Gim (2005, p.296) refutes Eckert (1991) with regard to the lacking concrete development policy in the 1910s and 1920s, in which the private market mechanism shall have driven the industrialization.

Note 25. Korea's ratio of foreign trade to GNI fell to $25.5 \%$ in 1965 and rose to $60.1 \%$ in 1996 , roughly the level of 1938 , subsequently skyrocketing to $113.5 \%$ in 2011.

Note 26. See Huh (2007) p.248 for example.

\section{Copyrights}

Copyright for this article is retained by the author(s), with first publication rights granted to the journal.

This is an open-access article distributed under the terms and conditions of the Creative Commons Attribution license (http://creativecommons.org/licenses/by/4.0/). 